\title{
Pertanggungjawaban Hukum Badan Pertanahan Nasional Terhadap Adanya Penerbitan Sertifikat Ganda
}

\author{
Hirwansyah \\ Fakultas Hukum, Universitas Bhayangkara Jakarta Raya \\ Email: hirwansyah.86@gmail.com
}

Received : 5 Feb 2021 | Revised : 23 Feb 2021 | Accepted : 13 Mar 2021 | Published : 10 Jun 2021

\begin{abstract}
The National Land Agency is responsible for the certificates it issues. The task of the National Land Agency is to manage and develop land administration, both based on the Basic Agrarian Law (UUPA) and other legislation covering the use, control, maintenance of land, management of land rights. Land administration and registration, and other matters relating to land issues based on policies established by the President. If there is an individual BPN who intentionally or negligently resulting in a loss to others due to an error in the issuance of the Certificate, then he is given the responsibility to compensate for the loss, it is even possible to pay lost profits. Even though the National Land Agency is not a state institution in the field of judiciary, the National Land Agency has the authority to resolve any land issues including the issue of dual certificates.
\end{abstract}

Keywords: Legal Liability, Double Certificate

\begin{abstract}
ABSTRAK
Badan Pertanahan Nasional bertanggung jawab atas sertifikat yang dikeluarkannya. Tugas Badan Pertanahan Nasional adalah mengelola dan mengembangkan administrasi pertanahan, baik berdasarkan Undang-Undang Pokok Agraria (UUPA) maupun peraturan perundangundangan lain yang meliputi pengaturan penggunaan, penguasaan, pemeliharaan tanah, pengurusan hak-hak atas tanah. Pengurusan dan pendaftaran tanah, dan hal-hal lainnya yang berkaitan dengan masalah pertanahan berdasarkan kebijakan yang ditetapkan oleh Presiden.Apabila adaoknum BPN yang dengan sengaja ataupun lalai yang mengakibatkan kerugian terhadap orang lain akibat kesalahan dalam penerbitan Sertifikat maka kepadanya diberikan tanggung jawab untuk mengganti kerugian bahkan dimungkinkan membayar kehilangan keuntungan. Walaupun Badan Pertanahan Nasional bukanlah lembaga negara dibidang yudikatif, namun Badan Pertanahan Nasional mempunyai wewenang untuk menyelesaikan setiap masalah pertanahan termasuk masalah sertifikat ganda.
\end{abstract}

Kata Kunci: pertanggungjawaban hukum, sertifikat ganda 


\section{PENDAHULUAN}

Badan Pertanahan Nasional merupakan salah satu lembaga Pemerintah di Indonesia yang tujuan dibentuknya Badan Pertanahan Nasional adalah untuk membuat sistem pengelolaan masalah pertanahan di Indonesia. Adapun dasar pembentukan BPN adalah Keputusan Presiden No.26 Tahun 1988. Direktorat Jenderal Agraria Departemen Dalam Negeri pun di ubah menjadi lembaga pemerintah non departemen untuk menjadi lembaga ini, kemudian sebagai panduan operasional Badan Pertanahan Nasional (BPN), pimpinan lembaga ini mengeluarkan SK No. 11/KBPN/1988 jo keputusan kepala BPN No. 1 tahun 1989 tentang organisasi dan tata kerja BPN di Provinsi, Kota dan Kabupaten.

Sertifikat hak atas tanah diatur dalam pasal 13 Peraturan Pemerintah No. 10 Tahun 1961 tentang pendaftaran tanah, khususnya dalam ayat (3) dirumuskan, bahwa : "Salinan buku tanah dan surat ukur setelah dijahit menjadi satu bersama - sama dengan suatu kertas sampul yang bentuknya ditetapkan oleh Menteri Agraria, disebut sertifikat dan diberikan kepada yang berhak". Selanjutnya dalam ayat (4) diaktakan : "Sertifikat tersebut pada ayat (3) pasal ini adalah surat tanda bukti hak yang dimaksud dalam pasal 19 UUPA".Ketentuan Undang - Undang dimaksud mengikat, sehingga setiap warga negara atau masyarakat sebagai pemilik hak atas tanah diwajibkan mendaftarkan tanah yang dikuasainya dan akan diberikan Salinan buku tanah yang disebut sertifikat yang merupakan surat tanda bukti hak. ${ }^{1}$ Sertifikat diterbitkan bertujuan untuk kepentingan pemegang hak yang bersangkutan sesuai dengan data fisik dan data yuridis yang telah didaftar dalam buku tanah. Sertifikat hanya boleh diserahkan kepada pihak yang namanya tercantum di dalam buku tanah yang bersangkutan sebagai pemegang hak atau kepada pihak lain yang dikuasakan olehnya.

Dalam hal atas suatu bidang tanah sudah diterbitkan sertifikat secara sah atas nama orang atau badan hukum yang memperoleh tanah tersebut dengan itikad baik dan secara nyata menguasainya, maka pihak lain yang merasa mempunyai hak atas tanah itu tidak dapat lagi menuntut pelaksanaan hak tersebut apabila dalam waktu 5 (lima) tahun sejak diterbitkannya sertifikat itu tidak mengajukan keberatan secara tertulis kepada pemegang sertifikat dan Kepala Kantor Pertanahan yang bersangkutan ataupun tidak mengajukan gugatan ke Pengadilan mengenai penguasaan tanah atau penerbitan sertifikat tersebut ${ }^{2}$

Keberadaan hak-hak perorangan atas tanah selalu bersumber pada Hak Bangsa Indonesia atas tanah pasal 1 ayat (1) Undang-undangNomor 5 Tahun 1960 Tentang Pokok Agraria, dan masing-masing hak penguasaan atas tanah dalam Hukum Tanah Nasional tersebut meliputi, hak bangsa Indonesia atas tanah pasal 1 ayat (1), dan hak menguasai Negara Pasal 2 ayat (1) dan (2) UU No 5Tahun 1960, serta hak-hak perorangan atas tanah yang terdiri dari hak-hak atas tanah (primer dan sekunder) dan hak jaminan atas tanah. ${ }^{3}$

Tata cara yang bisa digunakan untuk memperoleh hak atas tanah tergantung pada status tanah yang tersedia yaitu, Tanah Negara atau Tanah Hak. Jika tanah yang tersedia berstatus Tanah Negara, tata cara yang harusdigunakan untuk memperoleh

1 J. Andy Hartanto, 2013, Karakteristik Jual Beli Tanah Yang belum terdaftar hak atas tanahnya, Penerbit Laksbang justtia, Surabaya, hal.15.

${ }^{2}$ Ibid, Pasal, 32, (2).

${ }^{3}$ Sunario Basuki, Ketentuan Hukum Tata Nasional yang Menjadi Dasar dan Landasan Hukum Pemilikandan Penguasaan Tanah, Program Pendidikan Spesialis notaries Fakultas Hukum Universitas Indonesia, Hlm, 1. 
tanah tersebut adalah melalui permohonan hak dan jika yang tersedia berstatus Tanah Hak (hak-hak primer), maka tata cara yang dapat digunakan untuk memperoleh tanah tersebut di antaranya adalah melalui, pemindahan hak (jual-beli, hibah tukar, menukar). ${ }^{4}$ Setiap hak atas tanah yang diperoleh melalui acara permohonan hak wajib didaftarkan di kantor pertanahan BPN (dahulu Kantor Agraria) di setiap Kabupaten/Kotamadya.

Beberapa putusan pengadilan, khususnya Pengadilan Tata Usaha Negara yang sudah mempunyai Kekuatan Hukum Tetap (Inkrach) yang belum mendapat tindak lanjut dari BPN (eksekusi) karena BPN lalai bahkan tidak tegas dalam menjalankan tugas dan tanggung jawabnya dalam rangka menjamin kepastian hukum serta membela kepentingan pemegang atau pemilik hak atas tanah tersebut.

Sehubungan dengan itu, Undang-undang Nomor 5 Tahun 1960 $\begin{array}{lllll} & 19\end{array}$ memerintahkan diselenggarakannya pendaftaran tanah dalam rangka menjamin kepastian hukum dimaksud di atas. Pendaftaran tanah tersebut kemudian diatur lebih lanjut dengan Peraturan Pemerintah Nomor 10 tahun 1961 tentang Pendaftaran Tanah yang sampai saat ini menjadi dasar kegiatan pendaftaran tanah di seluruh Indonesia. ${ }^{5}$

Sengketa pertanahan khususnya sengketa yang berkaitan langsung dengan sertifikat hak milik, merupakan sengketa Hukum Administrasi Negara. Terjadinya suatu sengketa karena adanya objek yang disengketakan, artinya ada pangkal tolak sengketa yang timbul akibat adanya tindakan hukum pemerintah. Di dalam kepustakaan hukum administrasi, sengketa yang terjadi disebut sengketa administrasi, karena objek yang menjadi sengketa adalah keputusan administrasi (beschikking), yaitu keputusan yang dikeluarkan oleh Badan atau Pejabat Tata Usaha Negara. ${ }^{6}$

Pasal 19 ayat (2) huruf c UUPA yang mengatakan bahwa :"Pemberian suratsurat tanda bukti hak, yang berlaku sebagai alat pembuktian yang kuat". Pasal 23 ayat (2) yang mengatakan bahwa :"Pendaftaran termasuk dalam ayat (1) merupakan alat pembuktian yang kuat mengenai hapusnya hak milik serta sahnya peralihan dan pembebanan hak tersebut".Pasal 32 ayat (2) yang mengatakan bahwa :"Pendaftaran termaksud ini dalam ayat ini menyetakan alat pembuktian yang kuat mengenai peralihan serta hapusnya hak guna usaha, kecuali dalam hak itu hapus karena jangka waktunya berakhir".Pasal 38 ayat (2)UUPA yang mengatakan bahwa :"Pendaftaran termaksud dalam ayat (1) merupakan alat pembuktian yang kuat mengenai hapusnya hak guna bangunan serta sahnya peralihan hak tersebut, kecuali dalam hak itu hapus karena jangka waktunya berakhir" 7

Sengketa sertifikat hak milik atas tanah merupakan sengketa yang terjadi atas status keabsahan sertifikat hak milik yang dipunyai seseorang atau badan hukum perdata. Untuk itu pembatalan sertifikat oleh Pengadilan Tata Usaha Negara (PTUN), dilakukan terhadap sertifikat yang memiliki sengketa, misalnya kasus-kasus seperti sengketa Sertifikat Ganda dan Sertifikat Asli Tapi Palsu (cacat hukum dan administrasi). Semua permasalahan ini muncul pada proses pendaftaran tanah. Kasuskasus tersebut di atas merupakan penyebab terjadinya pembatalan sertifikat oleh BPN.

\footnotetext{
${ }^{4}$ Sunarto Basulki, GarisBesarHukum Tanah Indonesia Landasan Hukum Penguasaan dan Penggunaan tanah, Program Spesialis Nasional, hlm, 29.

${ }^{5}$ Peraturan Pemerintan Nomor 10 Tahun 1961, Tentang Pendaftaran Tanah.

${ }^{6}$ Sadjijono, Bab-Bab Pokok Hukum Administrasi Negara, Laksbang Pressindo, Yokyakarta, 2008, hlm, 132

${ }^{7}$ Pasal, 38, UUPA
} 


\section{PEMBAHASAN}

\section{Tanggung Jawab BPN Terhadap Penerbitan Sertifikat Ganda}

BPN bertanggung jawab atas sertifikat yang dikeluarkannya. Pasal 54 ayat (1) dan (2) Peraturan Kepala Badan Pertanahan Nasional Republik Indonesia Nomor 3 Tahun 2011 Tentang Pengelolaan Pengkajian Dan Penanganan Kasus Pertanahan menerangkan bahwa:

\section{Pasal 54}

1) BPN RI wajib melaksanakan putusan pengadilan yang telah memperoleh kekuatan hukum tetap, kecuali terdapat alasan yang sah untuk tidak melaksanakannya.

2) Alasan yang sah sebagaimana dimaksud pada ayat (1) antara lain:

a. Terhadap obyek putusan terdapat putusan lain yang bertentangan;

b. Terhadap obyek putusan sedang diletakkan sita jaminan;

c. Terhadap obyek putusan sedang menjadi obyek gugatan dalam perkara lain;

d. Alasan lain yang diatur dalam peraturan perundang-undangan.

Badan Pertanahan Nasional RI selain diberikan tugas dan tanggung jawab untuk melakukan kegiatan administratif pertanahan mulai dari pendataan tanah sampai penerbitan sertifikat, kepadanya juga diberikan kewajiban untuk melaksanakan putusan pengadilan TUN. Pembatalan keputusan mengenai pemberian suatu hak atas tanah karena keputusan tersebut mengandung cacat hukum dalam penerbitannya atau melaksanakan putusan pengadilan yang telah berkekuatan hukum tetap. ${ }^{8}$ Rumusan pembatalan hak atas tanah dimaksud belum lengkap karena hanya menyangkut pemberian hak atas tanahnya saja, meskipun dengan dibatalkan surat keputusan pemberian hak atas tanah, tentunya juga akan mengakibatkan pendaftaran dan sertifikatnya batal karena sesuai dengan PP No. 24 Tahun 1997, Surat Keputusan Pemberian Hak sebagai alat bukti pendaftaran hak dan penerbitan sertifikat.

Bahwa BPN tidak hanya bertanggung jawab sampai ada orang yang mengupayakan pada upaya administrasi, namun terhadap BPN diberikan beban untuk melaksanakan putusan PTUN yang berkaitan dengan tugas pokoknya yaitu penerbitan sertifikat. Sehubungan dengan hal ini sertifikat yang telah dibatalkan PTUN yang telah memiliki kekuatan hukum tetap haruslah ditindaklanjuti dalam hal melakukan pencabutan atau pembatalan sertifikat tersebut.

Sanksi perdata yang dapat diterapkan oleh Kantor Pertanahan akibat ketidak telitian dan ketidak cermatan dalam melakukan dan memeriksa data fisik, data yuridis dikenakan sanksi Pasal 1365 dan Pasal 1366 KUHPerdata yang menyebutkan:

Pasal 1365:

"Tiap perbuatan melanggar hukum, yang membawa kerugian kepada orang lain, mewajibkan kerugian itu, mengganti kerugian tersebut".

${ }^{8}$ Pasal 1 Angka 12 PMNA/KBPN Nomor 3 Tahun 1999 Tentang Tata Cara Pemberian dan Pembatalan Hak Atas Tanah Negara dan Pengololaan. 


\section{Pasal 1366:}

"Setiap orang bertanggung jawab tidak saja untuk kerugian yang disebabkan perbuatannya, tetapi juga untuk kerugian yang disebabkan kelalaian atau kurang hati-hatinya".

Tanggung jawab Kantor Pertanahan adanya sertipikat ganda adalah menerapkan sanksi perdata untuk mengganti rugi secara materiil, sanksi pidana dengan menghukum petugas ukur dan Kepala Kantor Pertanahan dengan Pasal 423 Jo. Pasal 424 ayat (1) KUHP dan Pasal 55 KUHP tentang Penyertaan (delneming) jo. Pasal 385 KUHP tentang perbuatan curang (bedrog), dan sanksi administratif berupa pemecatan petugas Kantor Pertanahan yang lalai dalam menjalankan tugasnya berdasar putusan pengadilan yang berkekuatan hukum tetap. Setelah semua penelitian dilakukan, BPN berkewajiban membatalkan salah satunya dan mengumumkannya kepada publik. ${ }^{9}$

Tangungjawab apabila dilihat dari sisi badan atau lembaga mana pertanggungjawaban itu diberikan, maka dibedakan menjadi dua jenis, yaitu:

1) Tanggungjawab eksternal; dan

2) Tanggungjawab internal. ${ }^{10}$

Tanggungjawab internal dapat berupa tanggungjawab bawahan kepada atasan, pada dasarnya terjadi dalam hubungan rutin antara atasan dengan bawahan. Sedangkan tanggungjawab eksternal merupakan tanggungjawab kepada pihak lain dalam hal ini misalnya tanggungjawab eksternal berupa tanggung gugat. Tanggung gugat ini muncul apabila terdapat individu atau badan hukum tertentu yang merasa dirugikan atas pelayanan yang diberikan oleh pemerintah.

Terkait dengan tanggunggugat yang ditujukan kepada pemerintah, menurut Tribunal de Conflicts tahun 1873, menetapkan 3 asas, yaitu:

1. Asas tanggung gugat negara atas kesalahan pejabatanya.

2. Tanggung gugat tunduk kepada peraturan yang memisahkan dan membedakannya dengan hukum privat.

3. Asas bahwa tanggung gugat tersebut merupakan yuridiksi dari peradilan administrasi. ${ }^{11}$

Tanggung gugat pemerintah setelah berlakunya Undang-Undang Nomor 5 Tahun 1986 Jo. Undang-Undang Nomor 9 tahun 2004 tentang Peradilan Tata Usaha Negara, ada dua jenis, yaitu: tanggung gugat sebagai konsekuensi atas kerugian karena implementasi dari KTUN dan tanggung gugat karena perbuatan pemerintah yang bertentangan dengan hukum. ${ }^{12}$

Tanggung jawab dalam hukum publik dikenal dengan tanggung jawab pribadi dan tanggungjawab jabatan. Tanggung jawab pribadi disebut dengan maladministrasi, dimana tanggung jawab ini terjadi karena adanya kesalahan pribadi yang diakukan oleh pejabat atau organ pemerintahan dalam memberikan suatu pelayanan publik seperti kurang hati-hati atau kelalaian sehingga menyebabkan timbulnya kerugian bagi individu atau suatu badan hukum tertentu. Seseorang dikatakan secara hukum

${ }^{9}$ Breaking News: EDDY LEKS ON LEGAL WORKSHOP OF PROPERTY LAW Januari 10,

${ }^{10}$ Lukman Hakim, Op. cit, hlm. 45

${ }^{11}$ Titiek Sri Djatmiati, Op. cit, hlm. 89

${ }^{12}$ Lukman Hakim, Op.cit, hlm. 46 
bertanggungjawab untuk suatu perbuatan tertentu adalah bahwa dia dapat dikenakan suatu sanksi dalam kasus perbuatan yang berlawanan. ${ }^{13}$

Dalam putusan Nomor 1318 K/Pdt/2017 Drs. Anak Agung Ngurah Jaya sebagai penggugat melawan Anak Agung Putri dan A.A. Ngurah Made Narottama. Tanah obyek sengketa yang ditenggarai adanya sertifikat ganda sedang disengketakan di Pengadilan Negeri Denpasar dalam perkara Nomor perdata Nomor 884/ Pdt.G/2015/PN.Dps; Mengingat proses penerbitan Sertifikat Hak Milik Nomor 10772, dengan Surat Ukur Nomor 4679/Jimbaran/2004 atas nama A.A.Ngurah Made Agung adalah salah atau keliru menunjuk lokasi tanah (eror in obyekto) sehingga terbitlah Sertifikat Hak Milik Nomor 10772, Surat Ukur Nomor 4679/Jimbaran/2004 atas nama A.A.Ngurah Made Agung oleh Terrgugat III/Termohon Kasasi III adalah cacat hukum dan melanggae hukum; Melainkan Tanah yang dimiliki oleh Salit Gde Meregeg yang berasal dari Br.Pemecutan yang dimohonkan Konversi oleh A.A. Ngurah Made Agung adalah tanah dari Salit Gde Meregeg yang berasal dari Br.Pemecutan dengan pipil Nomor 269, Persil 71a, Kls I, Luas asal 1.940 Ha, terletak di Kelurahan Jimbaran yang berbeda dengan kepemilikan dari Salit Gde Meregeg alias Gst Ngr Gde Regog dari Br.Abasan dengan Pipil Nomor 264,Persil 71 B,Kls II,Luas 0,930 Ha terletak di Br Menega, Kelurahan Jimbaran,Kuta, Badung, dan sebagian telah dipindah tangankan kepada I Sepir seluas 60 are, dan sisanya setelah diukur seluas $3145 \mathrm{~m}^{2}$ yang menjadi hak Penggugat / Pembanding /Pemohon Kasasi sebagai ahli waris dari Salit Gde Meregeg alias Gst Ngr Gde Regog dari Br.Abasan; Sehingga Sertifikat Hak Milik Nomor 10772,Surat Ukur Nomor 4679/Jimbaran/2004 atas nama A.A.Ngurah Made Agung yang diterbitkan oleh Termohon Kasasi III /dahulu TergugatIII/Terbanding III adalah cacat hukum dan melanggar hukum, dan karenanya secara hukum patut dan adil Sertifikat Hak Milik Nomor 10772,Surat Ukur Nomor 4679/Jimbaran/2004 atas nama A.A.Ngurah Made Agung untuk dibatalkan ( sesuai Pasal 62 ayat (1), (2) huruf e \& f Peraturan Kepala Badan Pertanahan Nasional Nomor 3 Tahun 2011, juncto Pasal 11 Peraturan Menteri Agraria dan Tata Ruang/ Kepala Badan Pertanahan Nasional Republik Indonesia Nomor 11 Tahun 2016 tentang Penyelesaian Kasus pertanahan.

Sehingga dengan demikian Putusan Pengadilan Tinggi Denpasar Nomor 146/Pdt/2016/PT.Dps, tanggal 5 Desember 2016 yang hanya sependapat dengan pertimbangan hukum Putusan Pengadilan Negeri Denpasar a quo yang tidak memberi pertimbangan yang cukup terhadap alat-alat bukti yang diajukan oleh para pihak, maka Putusan Pengadilan Tinggi Denpasar Nomor 146/Pdt/2016/PT.Dps,tanggal 5 Desember 2016 juga menjadi Putusan yang salah dalam penerapan hukumnya karena hanya semata-mata sependapat dengan pertimbangan hukum Putusan Pengadilan Negeri Denpasar a quo yang sudah nyata-nyata salah didalam menerapkan hukum, maka sudah seyogyanya putusan a quo patut untuk dibatalkan ( vide Yurisprudensi MARI Nomor 638 K/Sip/1969 tanggal 27 Juli 1970 jo Putusan MARI Nomor 492 K Sip/ 1970 tanggal 16 Desember 1970).

\section{Bentuk Penyelesaian Masalah Sertifikat Ganda Oleh BPN}

Dalam sebuah sertifikat tanah, dijelaskan beberapa hal diantaranya jenis hak atas tanah dan masa berlaku hak atas tanah, nama pemegangnya, keterangan fisik tanah, serta catatan mengenai peristiwa yang berhubungan dengan tanah (misalnya

${ }^{13}$ Jimly Asshiddiqie dan M. Ali Safa'at, 2006, Teori Hans Kelsen Tentang Hukum, Sekretariat Jendral dan Kepaniteraan Mahkamah Konstitusi RI, Jakarta, hlm. 61 
catatan jual-beli). Sertifikat itu bisa dimanfaatkan sebagai agunan menambah modal usaha dan meningkatkan harga jual tanah. Jenis hak atas tanah dalam sertifikat tanah mencantumkan jenis hak atas tanah si pemiliknya diantaranya Hak Guna Bangunan (HGB), Hak Milik, Hak Pakai, Hak Guna Usaha (HGU), dan Hak Pengelolaan.

Masa berlaku Hak Milik tidak ada batasan waktunya.Penerbitan sertipikat hak atas tanah yang dikeluarkan oleh Kantor Pertanahan berupa sertipikat tanah hak milik yang melibatkan pihak pemohon, para pemilik tanah yang bersebelahan, pamong desa dan pihak instansi yang terkait untuk memperoleh penjelasan mengenai surat-surat sebagai alas hak yang berhubungan dengan permohonan sertipikat, sehingga penjelasan dari pihak terkait memiliki peluang untuk timbul sertipikat cacat hukum. ${ }^{14}$

Sertipikat hak atas tanah sebagai alat bukti surat belum dapat memenuhi keinginan masyarakat, karena dalam prosesnya sering terjadi sengketa/konflik dalam hal menentukan siapakah yang berhak atas obyek tanah tersebut.Proses penyelesaian sengketa/konflik tanah memerlukan waktu yang cukup lama apabila tidak dapat diselesaikan melalui jalur mediasi antara para pihak yang bersengketa dan Kantor Pertanahan selaku mediator. ${ }^{15}$

Sertifikat tanah ganda adalah terjadinya penerbitan lebih dari satu sertifikat pada obyek tanah yang sama. ${ }^{16}$ terjadinya penerbitan lebih dari satu sertifikat pada obyek tanah yang sama. Hal ini seharusnya tidak dimungkinkan terjadi, karena untuk menerbitkan sebuah sertifikat tanah, maka BPN harus melihat pada buku induk tanah tersebut apakah tercatat telah diterbitkan sertifikat atau belum.

Perpres Nomor 10 tahun 2006 tentang Badan Pertanahan Nasional yang menyatakan bahwa BPN melaksanakan tugas dibidang pertanahan secara nasional regional dan sektoral. Bahkan melalui Proses yang sama, pemerintah juga telah memperkuat peran dan posisi BPN dengan membentuk Deputi V yang secara khusus mengkaji dan menyelesaikan sengketa dan konflik pertanahan. ${ }^{17}$

Sesuai peraturan Kepala BPN-RI No. 3 Tahun 2006 tentang organisasi dan tata kerja BPN-RI, pengkajian dan penanganan sengketa dan konflik pertanahan merupakan bidang Deputi V yang membawahi: ${ }^{18}$

a) Direktorat konflik pertanahan

b) Direktorat sengketa pertanahan

c) Direktorat perkara pertanahan

Pasal 346 Peraturan Kepala BPN-RI No. 3 Tahun 2006 Badan Pertanahan Nasional selalu mengupayakan solusi penyelesaian sengketa pertanahan dengan berdasarkan peraturan perundangan yang berlaku dengan memperhatikan rasa keadilan dan menghormati hak dan kewajiban masingmasing pihak. Langkah-langkah penyelesaian sengketa yang mereka atau pihak BPN tempuh adalah musyawarah.Begitu juga dalam sengketa sertifikat ganda, BPN juga berwenang melakukan negosiasi, mediasi dan fasilitasi terhadap pihak-pihak yang bersengketa

14 Ali Achmad Chomzah, Hukum Pertanahan Seri Hukum Pertanahan III-Penyelesaian Sengketa Hak Atas Tanah dan Seri Hukum Pertanahan IV-Pengadaan Tanah Instansi Pemerintah, Prestasi Pustaka, Jakarta, 2003, Hlm.18

${ }^{15}$ Syahrial Abbas, Mediasi dalam perspektif hukum syari'ah”, hukum adat, hukum nasional, Kencana Prenada Media Group, Jakarta, 2009, hlm, 2

${ }^{16}$ http://kantorhukumkalingga.blogspot.co.id/2013/06/penyelesaian-permasalahan-hukum.

${ }^{17}$ Bernhard Limbong, Hukum Agraria Nasional hlm 412

${ }^{18}$ Elza Syarief Op.cit, hlm 277 
dan menggagas suatu kesepakatan di antara para pihak. ${ }^{19}$ Kantor wilayah BPN yaitu di Provinsi dan Kabupaten/Kotamadya, hanya bisa sampai pada putusan penyelesaian masalah, sedangkan tindak lanjut administrasi pertanahan tetap dilakukan BPN.

Untuk meminimalkan sengketa pertanahan dalam hal ini sertifikat ganda, maka dalam hal ini peran yang dilakukan BPN sebagai pelayan masyarakat antara lain adalah: ${ }^{20}$

1. Menelaah dan mengelolah data untuk menyelesaikan perkara di bidang pertanahan.

2. Menampung gugatan-gugatan, menyiapkan bahan memori jawaban, menyiapkan memori banding, memori/kontra memori kasasi, memori/kontra memori peninjauan kasasi atas perkara yang diajukan melalui peradilan terhadap perorangan dan badan hukum yang merugikan negara.

3. Mengumpulkan data masalah dan sengketa pertanahan.

4. Menelaah dan menyiapkan konsep keputusan mengenai penyelesaian sengketa atas tanah.

5. Menelaah dan menyiapkan konsep keputusan pembatalan hak atas tanah yang cacat administrasi dan berdasarkan kekuatan putusan peradilan.

6. Mendokumentasi.

BPN juga memiliki mekanisme tertentu dalam menangani dan menyelesaikan perkara atau sengketa pertanahan dalam hal ini termasuk juga sengketa sertifikat ganda yaitu: ${ }^{21}$

a) Sengketa tanah biasanya diketahui oleh BPN dari pengaduan.

b) Pengaduan ditindaklanjuti dengan mengidentifikasikan masalah. Dipastikan apakah unsur masalah merupakan kewenangan BPN atau tidak.

c) Jika memang kewenangannya, maka BPN meneliti masalah untuk membuktikan kebenaran pengaduan serta menentukan apakah pengaduan beralasan untuk diproses lebih lanjut.

d) Jika hasil penelitian perlu ditindaklanjuti dengan pemeriksaan data fisik administrasi serta yuridis, maka kepala kantor dapat mengambil langkah berupa pencegahan mutasi (status quo).

e) Jika permasalahan bersifat strategis, maka diperlukan pembentukan beberapa unit kerja. Jika bersifat politis, sosial, dan ekonomis maka tim melibatkan institusi berupa DPR atau DPRD, departemen dalam negeri, pemerintah daerah terkait.

f) Tim akan menyusun laporan hasil penelitian untuk menjadi bahan rekomendasi penyelesaian masalah

\section{Bentuk Penyelesaian Masalah Sertifikat Ganda di Indonesia}

\section{a. Penyelesaian Sengketa}

Proses penyelesaian sengketa (Disputes Resolution), seperti melalui misalnya melalui lembaga-lembaga yang berwenang Badan Arbritase Nasional Indonesia (BANI), kemudian melalui Negoisasi, Mediasi, Konsiliasi, Mediasi, selain itu dapat juga melalui Badan Pertanahan Nasional. Beberapa cara penyelesaian sengketa tanah di Indonesia dapat ditempuh melalui beberapa cara berikut ini:

\footnotetext{
${ }^{19}$ Ibid., hlm 276

${ }^{20}$ Ibid

${ }^{21}$ Ibid., hlm 277
} 
1) Penyelesaian Sengketa Tanah Melalui Pengadilan (Litigasi).

Negara Indonesia sebagai suatu negara hukum berdasarkan Pancasila sebagaimana diatur dalam Pasal 1 ayat (3) UUD NRI 1945 yang menyatakan bahwa Negara Indonesia adalah negara hukum. Indonesia sebagai negara hukum, diperlukan suatu lembaga yang mempunyai kewenangan untuk menyelesaikan sengketa yang terjadi di masyarakat, baik sengketa antara masyarakat dengan masyarakat maupun antara masyarakat dengan pemerintah. Dalam negara hukum berdasarkan Pancasila lembaga yang mempunyai kewenangan untuk menyelesaikan sengketa disebut lembaga peradilan atau lembaga yudikatif. Sementara itu dalam kaitannya dengan penyelesaian sengketa perkebunan melalui proses lembaga peradilan disebut sebagai proses penyelesaian sengketa litigasi.

2) Penyelesaian Sengketa Non Litigasi atau Penyelesaian Sengketa Alternative (Alternative Disputes Resolution).

Penyelesaian sengketa non litigasi sering juga disebut dengan penyelesaian sengketa alternative (alternative disputes resolution). Alternatif penyelesaian sengketa merupakan ekspresi responsif atas ketidakpuasan (dissatisfaction) penyelesaian sengketa melalui proses litigasi yang konfrontatif dan zwaarwichtig (njelimet - bertele-tele). Thornas J. Harron mengatakan bahwa: "masyarakat sudah jemu mencari penyelesaian sengketa melalui litigasi (badan peradilan), mereka tidak puas atas sistem peradilan (dissatisfied with the judicial system), disebabkan cara penyelesaian sengketa yang melekat pada sistem peradilan sangat bertele-tele (the delay inherent in a system) dengan cara-cara yang sangat merugikan, antara lain: buang-buang waktu (a waste of time), biaya mahal (very expensive), mempermasalahkan masa lalu, bukan menyelesaikan masalah masa depan, membuat orang bermusuhan (enemy), melumpuhkan para pihak (paralyze people)."

Pada saat ini, kebanyakan sengketa pertanahan dalam hal ini sertifikat ganda diselesaikan melalui 3 (tiga) cara, yaitu: ${ }^{22}$

1. Penyelesaian secara langsung oleh pihak dengan musyawarah Dasar musyawarah untuk mufakat tersirat dalam pancasila sebagai dasar kehidupan bermasyarakat Indonesia dan dalam UUD 1945. Musyawarah dilakukan diluar pengadilan dengan atau tanpa mediator. Mediator biasanya dari pihakpihak yang memiliki pengaruh misalnya Kepala Desa/Lurah, ketua adat serta pastinya Badan Pertanahan Nasional. Dalam penyelesaian sengketa pertanahan lewat musyawarah, satu syaratnya adalah bahwa sengketa tersebut bukan berupa penentuan tentang kepemilikan atas tanah yang dapat memberikan hak atau menghilangkan hak seseorang terhadap tanah sengketa, dan diantara pihak bersengketa memiliki kekebaratan yang cukup erat serta masih menganut hukum adat setempat.

2. Melalui arbitrase dan alternative penyelesaian sengketa Arbitrase adalah penyelesaian perkara oleh seorang atau beberapa arbiter (hakim) yang diangkat berdasarkan kesepakatan/persetujuan para pihak dan disepakati bahwa putusan yang diambil bersifat mengikat dan final. Persyaratan utama yang harus dilakukan untuk dapat mempergunakan arbitrase sebagai penyelesaian sengketa adalah adanya kesepakatan yang dibuat dalam bentuk tertulis dan disetujui oleh

${ }^{22}$ Elza Syarief, Op Cit, hlm. 375 
para pihak. ${ }^{23}$ Jika telah tertulis suatu klausula arbitrase dalam kontrak atausuatu perjanjian arbitrase, dan pihak lain menghendaki menyelesaikan masalah hukumnya ke pengadilan, maka proses pengadilan harus ditunda sampai proses arbitrase tersebut diselesaikan dalam lembaga arbitrase. Dengan demikian pengadilan harus dan wajib mengakui sserta menghormati wewenang dan fungsi arbiter.

3. Penyelesaian sengketa melalui badan peradilan Sesuai dengan peraturan yang berlaku di Indonesia, pada umumnya penyelesaian sengketa pertanahan yang terkait sengketa kepemilikan diserahkan ke peradilan umum, terhadap sengketa keputusan Badan Pertanahan Nasional melalui Peradilan Tata Usaha Negara dan sengketa menyangkut tanah wakaf diajukan ke Peradilan Agama. Berdasarkan penjelasan tentang spesifikasi dari lembaga penyelesaian sengketa baik lembaga litigasi dan lembaga non litigasi, sampai saat ini jelas bahwa semua cara itu tidak dapat menyelesaikan masalah sengketa pertanahan secara tuntas dalam waktu yang singkat, malah cenderung berlarut-larut.

Faktanya, proses mediasi yang dilakukan BPN tidak maksimal dalam menyelesaikan sengketa pertanahan yang ada saat ini untuk itulah mengapa BPN sangat sulit untuk mewujudkan seluruh visi, misi dan program-program strategis yang diembannya. ${ }^{24}$ BPN mengalami kendala dalam mengatasi sengketa pertanahan khususnya permasalahan sertifikat ganda dikarenakan tumpangtindihnya peraturan atau regulasi yang ada.

\section{KESIMPULAN}

Badan Pertanahan Nasional, bertanggung jawab atas terbitnya dua sertifikat diatas lahan yang sama, baik yang dilakukan atas kelalain atau tidak sengaja maupun dilakukan dengan sengaja. Terbitnya sertifikat ganda oleh BPN berimplikasi terjadinya permasalahan hukum/sengketa yang mengakibatkan kerugian kepada pemilik lahan yang bersengketa, BPN tidak hanya bertanggungjawab melaksanakan putusan pengadilan dengan mencabut atau melakukan pembatalan terhadap sertifikat yang sudah memiliki keputusan hukum tetap, tetapi BPN juga bertanggung jawap baik secara atministrasi, secara perdata, maupun secara pidana.

Bentuk Penyelesaian Sengketa Oleh BPN walaupun Badan Pertanahan Nasional bukanlah lembaga negara dibidang yudikatif, namun Badan Pertanahan Nasional mempunyai wewenang untuk menyelesaikan setiap masalah pertanahan termasuk masalah sertifikat ganda, namun wewenang ini hanya sebatas wewenang administrasi saja, yaitu pembatalan atau pencabutan suatu sertifikat yang dikeluarkan oleh BPN itu sendiri. Langkah-langkah penyelesaian sengketa yang dilakukan oleh BPN dalam penyelesaian masalah sertifikat ganda adalah arbitrase, negosiasi, mediasi dan musyawarah.

\section{SARAN}

Penyelesaian sengketa pertanahan umumnya melalui proses litigasi, memakan waktu yang lama dan biaya yang lumayan besar. Penyelesaian sengketa sertifikat ganda

23 Jimmy Joses Sembiring, Cara Menyelesaikan Sengketa Diluar Pengadilan, Visimedia, Jakarta, 2011, hlm. 58.

${ }^{24}$ Bernhard Limbong, Hukum Agraria Nasional, hlm. 412 
biasanya dapat diselesaikan melalui 3 (tiga) cara yaitu dengan melalui Musyawarah, melalui Arbitrase serta melalui Pengadilan.

Hendaknya Pemerintah mengeluarkan aturan tegas, mempermudah penyelesaian sengketa Pertanahan, membuat pengadilan bersifat khusus pertanahan tanpa adanya proses banding, langsung upaya kasasi agar tidak memakan waktu yang lama serta menghukum oknum BPN apabila terbukti bersalah dengan memberikan sanksi penurunan pangkat / golongan, pemecatan dan memberikan ganti rugi yang layak kepada pihak yang dirugikan, serta pidana maksimal agar menjadi efek jera bagi oknum BPN dan Mafia tanah.

\section{DAFTAR PUSTAKA}

\section{Buku}

Ali Achmad Chomzah, Hukum Pertanahan Seri Hukum Pertanahan III-Penyelesaian Sengketa Hak Atas Tanah dan Seri Hukum Pertanahan IV-Pengadaan Tanah Instansi Pemerintah, Prestasi Pustaka, Jakarta, 2003

Bernhard Limbong, Hukum Agraria Nasional

J. Andy Hartanto, 2013, Karakteristik Jual Beli Tanah Yang belum terdaftar hak atas tanahnya, Penerbit Laksbang justtia, Surabaya

Jimly Asshiddiqie dan M. Ali Safa'at, 2006, Teori Hans Kelsen Tentang Hukum, Sekretariat Jendral dan Kepaniteraan Mahkamah Konstitusi RI, Jakarta

Jimmy Joses Sembiring, Cara Menyelesaikan Sengketa Diluar Pengadilan, Visimedia, Jakarta, 2011

Sadjijono, Bab-Bab Pokok Hukum Administrasi Negara, Laksbang Pressindo, Yokyakarta, 2008

Sahrul Iswandi, Kantor Pertanahan Kabupaten Sidoarjo, sertipikat ganda pada umumnya disebut dengan sertipikat hak atas tanah yang dimiliki oleh dua orang yang berbeda menempati obyek yang sama (tanah

Sunario Basuki, Ketentuan Hukum Tata Nasional yang Menjadi Dasar dan Landasan Hukum Pemilikandan Penguasaan Tanah, Program Pendidikan Spesialis notaries Fakultas Hukum Universitas Indonesia

Sunarto Basulki, GarisBesarHukum Tanah Indonesia Landasan Hukum Penguasaan dan Penggunaan tanah, Program Spesialis Nasional

Syahrial Abbas, Mediasi dalam perspektif hukum syari'ah”, hukum adat, hukum nasional, Kencana Prenada Media Group, Jakarta, 2009 


\section{Perundang-undangan}

Undang - Undang Dasar 1945 Pasal

Peraturan Pemerintan Nomor 10 Tahun 1961, Tentang Pendaftaran Tanah.

PMNA/KBPN Nomor 3 Tahun 1999 Tentang Tata Cara Pemberian dan Pembatalan Hak Atas Tanah Negara dan Pengololaan.

\section{Jurnal}

Breaking News: EDDY LEKS ON LEGAL WORKSHOP OF PROPERTY LAW Januari 10, 2021

\section{Internet}

http://kantorhukumkalingga.blogspot.co.id/2013/06/penyelesaian-permasalahanhukum. 